\title{
How Climate Change Impacts Energy Load Demand for Commercial and Residential Buildings in a Large City in Northern China
}

\author{
Mingcai Li ${ }^{1 *}$, Mingming Xiong ${ }^{1}$, Cao Xiang², Jingfu Cao ${ }^{1}$ \\ ${ }^{1}$ Tianjin Climate Center, Tianjin, China \\ ${ }^{2}$ School of Environmental Science and Engineering, Tianjin University, Tianjin, China
}

Received: 9 August 2017

Accepted: 29 October 2017

\begin{abstract}
Exploring building energy demands under the conditions of climate change can provide a basis for promoting building energy efficiency. The heating and cooling loads of commercial and residential buildings with different energy-saving standards from 1961-2009 in a large city in northern China were simulated and their responses to climate change and variability were analyzed. The results showed that the heating load for commercial buildings significantly decreased from 1961 to $2009(P<0.01)$, whereas the cooling load weakly but not significantly increased over these 49 years $(P>0.05)$. This may indicate that continuous rising temperatures in the future may apparently decrease heating load, but not largely increase energy load for cooling. The heating loads in all types of residential buildings showed a large and significant decrease from 1961 to $2009(P<0.01)$. However, decreasing rate gradually decreased from the first- to the third-stage energy-saving buildings, indicating decreasing sensitivity to climate change with enhancement of energy-saving standards. The variations of heating loads are dominantly controlled by the mean air temperature, which can explain up to $90 \%$ of the heating load. The climate change influence on the cooling load of a commercial building is dependent on month. Cooling load is dominantly related to air temperature in June and September, whereas it relates to the combination of humidity and temperature in July and August. These results may indicate that improvement of energy efficiency for building cooling should be considered by the combined effects of humidity and temperature rather than a single temperature.
\end{abstract}

Keywords: energy load, commercial buildings, residential buildings, energy standards, climate parameters

\section{Introduction}

There is growing concern about energy consumption and its implications for the environment, which has

*e-mail: li_mingcai@163.com included issues facing building professionals and energy policy makers [1-2]. Buildings play a very important role in the energy demand sector as they account for more than $30 \%$ of China's total national energy consumption, and which is projected to increase to $35 \%$ by 2020 [2-3]. As a dominant portion of building energy consumption, up to $65 \%$ of building energy was used for heating and air conditioning, which is much 
higher than that in developed European countries [3]. Therefore, it is necessary to take efficient building energy conservation measures, especially for heating or cooling energy consumption, to decrease the total energy consumption and to further ensure sustainable energy development. The energy efficiency in China is still very low compared to other countries with similar climate conditions to China [4].

With double-digit rates of economic growth for much of the past several decades, China has been the biggest emitter of carbon dioxide and accounts for around $23.4 \%$ of global $\mathrm{CO}_{2}$ emissions, which has huge implications for energy consumption and the environment [3]. Climate conditions are a basic factor that influences building energy consumption. The changing climate largely promotes an increase in energy consumption and greenhouse gas emissions, making the Chinese government take efficient measures to promote building energy efficiency and emissions of atmospheric pollutants, especially in Northern China. In China, many efforts, e.g., a series of building energy standards, have been made to improve the energy efficiency of buildings since 1986, when the first building code was introduced [3]. However, due to the lack of detailed information on the impacts of the changing climate on building energy consumption [4], targeted adaptation measures could not be efficiently made, which makes energy consumption for building heating or cooling greater than that of Northern European areas with similar climates [3]. It is very necessary to determine the impact of the changing climate on building energy consumption to develop efficient targeted adaptation technologies to promote energy savings and greenhouse gas emission reduction [5-6].

However, knowledge concerning climate change's effect on building energy consumption is rather limited in China. Particularly, attempts to determine energy consumption for different types of buildings with climate, to our knowledge, has not been reported except for studies by Wan et al. [7] and Li et al. [8]. More previous studies on building cooling and heating energy demands are mainly according to simplified analyses using constant increases in the annual average temperature or changes in cooling or heating degree days [9-10]. These may lead to less inaccurate results regarding the impacts of climate change on the energy consumption of different buildings due to lacking changes in humidity, solar radiation, and wind speed if the degree days are without any adjustment of appropriate parameters [11-12].

The transient systems simulation program (TRNSYS) is a useful tool for simulating indoor conditions and energy consumption for heating and cooling, and has been used in several previous studies [2, 13-14]. At present, a building energy efficiency of at least $50 \%$ is required in most regions of China, whereas some large cities (such as Beijing, Shanghai, and Tianjin) are asked to follow standards of energy efficiency of at least $65 \%$ [3]. In order to provide a scientific basis for promoting building energy efficiency, especially considering continuous climate change, some previous studies analyzed the climate change impacts on building energy consumption [2, 7, 13-16] and meteorological parameters for building energy-saving design [17] at the national scale. However, previous studies almost focused on climate change impacts on energy consumption for the same building (office or commercial buildings) in different climates. Under the same climate conditions, how energy consumption of different buildings, especially different energy-saving standard buildings, responds to climate change is rather limited [8]. In this study, we selected commercial buildings and residential buildings with different energy-saving standards in a large city in China, and their energy load was simulated with a simulation tool (TRNSYS). The purpose of this study was to assess the rate of possible change in energy demand for heating and cooling in commercial and residential buildings with different energy saving standards in Tianjin. In addition, the impact of climatic parameters on building energy load was analyzed.

\section{Material and Methods}

\section{Study Area}

Tianjin is the second largest city by urban population in northern China, following Beijing (Fig. 1, 39 $9^{\circ} 10^{\prime} \mathrm{N}$, $\left.117^{\circ} 10^{\prime} \mathrm{E}\right)$, with a population of approximately 10 million across $11,919 \mathrm{~km}^{2}$. Tianjin has a semi-moist continental monsoon climate, with monsoon prevailing all year round and four distinct seasons. The annual average precipitation is $570 \mathrm{~mm}$ with most occurring during June to August. The mean annual temperature is $12.3^{\circ} \mathrm{C}$, with annual extremes of $41.7^{\circ} \mathrm{C}$ and $-23.3^{\circ} \mathrm{C}$.

\section{Selection of Buildings}

Commercial buildings generally consume the largest portion of total energy - far more than office buildings. Particularly in recent years, commercial buildings rapidly developed in Tianjin city (other large cities may be the same) with the development of the Chinese economy. But compared with developed countries, the energy-saving efficiency is much lower in the process of heating or cooling due to lacking consideration of climate effect. Therefore, commercial buildings in Tianjin city were selected to analyze the response of energy consumption to climatic parameters. Residential buildings were selected because they account for another large portion of total energy consumption, especially for heating. Determining climate effect on heating energy consumption is beneficial for not only making measures to save energy, but also decreasing emissions of pollutants because the haze event that has occurred in eastern China in recent years is to a large extent related to heating coal consumption. In addition, Tianjin, as the demonstration city of energy savings 


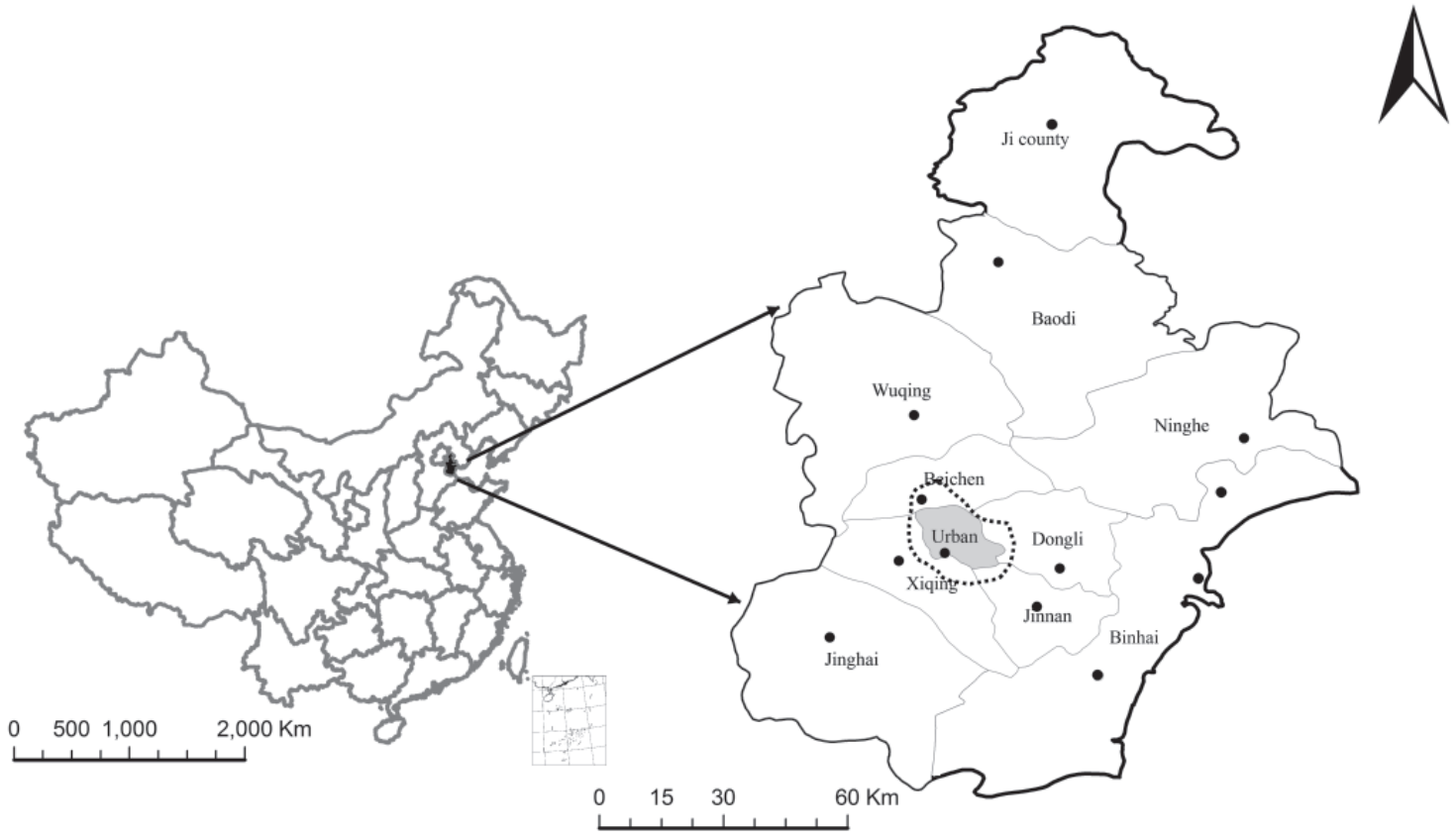

Fig. 1. The location of the study area in Tianjin, China; solid circles indicate the selected meteorology in Tianjin city, the central meteorological station represents the urban area (gray area), and the dotted line represents the outer ring road surrounding the dominant urban built-up area of the city.

for residential buildings in China, initiated third-stage energy saving standards for residential buildings on 1 January 2005. Compared with the first- and secondstage energy-saving standards (initiated in 1988 and 2002, respectively), third-stage energy-saving buildings should decrease energy load by $65 \%$ compared with traditional buildings. This should decrease the total energy consumption of buildings of third-stage energysaving standards to approximately $14 \mathrm{~W} / \mathrm{m}^{2}$ per year. By choosing different energy-saving standard residential buildings, the sensitivity of energy load of different energy-saving standards to climate change can be determined. Commercial and residential buildings in the central urban area of Tianjin (Fig. 1) were selected and then the energy loads of commercial and residential buildings with three different energy-saving standards were simulated and analyzed.

\section{Multi-Year Building Energy Consumption Simulation}

Hour-by-hour energy consumption simulations for each of the 49 years (1961-2009) were conducted using the TRNSYS simulation tool. The cooling season for commercial building is set from 15 June to 15 September and from 15 November to 15 March in the next year for the heating season. According to previous studies, building energy consumption simulation using different simulation tools is an accepted analysis technique and has been widely used, although there are differences between simulations and actual energy consumption in practice $[1-2,6]$. However, in terms of a comparative energy consumption study, the simulated results give a good indication of the likely percentage change and any underlying trends [2]. To conduct the simulation of energy load, two types of dominant inputs were considered. First, 8,760 hourly records of weather data (i.e., dry bulb temperature, DBT; wet bulb temperature, WBT; global solar radiation, GSR; wind speed, WS; wind direction, WD) for each year from 1961 to 2009 were used for the energy consumption simulation. Quality control and homogeneity of the selected meteorological data have been strictly tested to ensure the reliability and accuracy of the data. Station relocation is one of the most important factors that causes the discontinuities in temporal series of temperature [17]. There was only once relocation in Tianjin in 2001 during the period of 1961-2009, with no apparent change in altitude and $4 \mathrm{~km}$ variation in horizontal distance. Therefore, we can find no apparent effect of station relocation on the homogeneity of meteorological data. Detailed information on quality control and homogeneity test can be found in previous studies [17]. Historical meteorological data from 1961 to 2009 of a meteorological station of the urban area of Tianjin was selected to perform the study. WS and WD were collected directly from the observed data. The DBT and relative humidity $(\mathrm{RH})$ recorded four times a day before 2006 were collected to generate the hourly DBT and RH through cubic spline interpolation (having been recorded hourly since 2006). The WBT can be calculated from DBT and RH by the following Eq. 1 of Stull et al. [18]: 


$$
\begin{aligned}
T_{w}= & T \operatorname{atan}\left[0.151977(\mathrm{RH} \%+8.313659)^{1 / 2}\right] \\
& +\operatorname{atan}(\mathrm{T}+\mathrm{RH} \%)-\operatorname{atan}(\mathrm{RH} \% \\
& -1.6763310+0.00391838(\mathrm{RH} \%)^{3 / 2} \\
& \operatorname{atan}(0.023101 \mathrm{RH} \%)-4.686035
\end{aligned}
$$

...where $\mathrm{T}$ is dry bulb temperature, and $\mathrm{RH}$ is relative humidity.

Hourly GSR was generated from the daily total solar radiation using the Collores-Perein and Rabl model and was adjusted for three weather conditions (rainy, foggy, and sunny). The generated hourly DBT, RH, and GSR and the observed hourly data in the most recent 5 years (2006-2010) were compared to reveal the reliability of the generated data. According to our earlier works, the calculated and observed hourly data show very similar patterns and the regression coefficients of the calculated and observed values were all above 0.95 with a 0.001 level of significance, confirming the reliability and accuracy of the calculated data [8]. The energy load-related building parameters were input for the TRNSYS simulation project. A generic commercial building (with year-round air-conditioning) was selected for the energy consumption simulation. The chosen commercial building was a 5-story building with curtain wall design, $4.5 \mathrm{~m}$ floor-to-floor height, and total gross floor area (GFA) of $24,320 \mathrm{~m}^{2}$. A 9-story residential building with a total area of $2,790 \mathrm{~m}^{2}$ and $2.8 \mathrm{~m}$ floorto-floor height and significantly different building envelopes according to the prevailing architectural and engineering practices and design/energy codes was selected for simulating the energy consumption of residential buildings with different energy-saving standards. A summary of the key design parameters is shown in Table 1. The opening time is 08:00 to 21:00 for both commercial buildings' air-conditioning and heating systems. The heating season for residential buildings is the same for commercial buildings, but the run-time is the whole day.
In order to guarantee reliability of the simulated data, hourly energy load was monitored during the heating period in 2010-2011 and the cooling period in 2010. The measured and simulated energy load showed very similar hourly patterns, and high correlation was found [8]. According to the Bland-Altman analyses, the difference was relatively smaller and only a few points were outside the $95 \%$ limits of agreement [8]. This indicates that the TRNSYS can be efficiently used to simulate the real energy load of a building for heating or cooling requirement. According to the simulated hourly energy load data, it was easy to obtain the daily or monthly energy load. Building cooling and heating loads were analyzed and compared for each type of building.

\section{Statistical Analysis}

Simple linear regression analysis was performed to examine the yearly variations of the cooling/ heating loads for the commercial and different energy saving-standard residential buildings. Both the climate parameters themselves and their interaction are critical for the impact on energy load, i.e., a change in one parameter affects the others. Therefore, multiple stepwise linear regressions were used to identify the dominant variables affecting the building energy load. Briefly, stepwise multiple linear regression on the building cooling or heating loads of each month was performed against the possible climatic parameters, i.e., mean temperature, maximum temperature, minimum temperature, wet bulb temperature, solar radiation, sunshine duration, and wind speed in the cooling or heating periods. All statistical analyses were performed using SPSS 11.0 for Windows, and all significance levels were set at $P<0.05$.

\section{Yearly Variations of Cooling/Heating Loads}

\begin{tabular}{|c|c|c|c|c|c|c|c|c|c|c|c|c|c|}
\hline \multirow{3}{*}{$\begin{array}{l}\text { Building } \\
\text { type }\end{array}$} & \multirow{2}{*}{\multicolumn{3}{|c|}{$\begin{array}{l}\text { Building envelope } \\
\text { HTC }\left(\mathrm{W} / \mathrm{m}^{2 \circ} \mathrm{C}\right)\end{array}$}} & \multirow{2}{*}{\multicolumn{3}{|c|}{$\begin{array}{c}\begin{array}{c}\text { Indoor design } \\
\text { condition }\end{array} \\
\text { Summer/Winter }\end{array}$}} & \multicolumn{3}{|c|}{ Internal load density } & \multicolumn{4}{|c|}{ Window-to-wall ratio } \\
\hline & & & & & & & \multirow{2}{*}{$\begin{array}{l}\text { Occupancy } \\
\left(\mathrm{m}^{2} / \text { person }\right)\end{array}$} & \multirow{2}{*}{$\begin{array}{c}\text { Lighting } \\
\left(\mathrm{W} / \mathrm{m}^{2}\right)\end{array}$} & \multirow{2}{*}{$\begin{array}{c}\text { Equipment } \\
\left(\mathrm{W} / \mathrm{m}^{2}\right)\end{array}$} & \multirow[t]{2}{*}{ East } & \multirow[t]{2}{*}{ South } & \multirow[t]{2}{*}{ West } & \multirow[t]{2}{*}{ North } \\
\hline & Wall & Roof & Floor & $\begin{array}{c}\mathrm{T} \\
\left({ }^{\circ} \mathrm{C}\right)\end{array}$ & $\begin{array}{l}\mathrm{RH} \\
(\%)\end{array}$ & $\begin{array}{l}\text { ACR } \\
(1 / h)\end{array}$ & & & & & & & \\
\hline Commercial & 0.53 & 0.48 & 2.04 & $25 / 20$ & $60 / 30$ & $1.50 / 1.5$ & 3 & 12 & 13 & 0.48 & 0.46 & 0.30 & 0.28 \\
\hline $\begin{array}{l}1^{\text {st }} \text { step } \\
\text { residential }\end{array}$ & 1.57 & 0.90 & 0.49 & 18 & 30 & 0.51 & 12 & 1.3 & 2.5 & 0.30 & 0.35 & 0.30 & 0.20 \\
\hline $\begin{array}{l}2^{\text {nd }} \text { step } \\
\text { residential }\end{array}$ & 0.89 & 0.80 & 0.49 & 18 & 30 & 0.51 & 12 & 1.3 & 2.5 & 0.30 & 0.35 & 0.30 & 0.25 \\
\hline $\begin{array}{l}3^{\text {rd }} \text { step } \\
\text { residential }\end{array}$ & 0.55 & 0.46 & 0.49 & 18 & 30 & 0.51 & 12 & 1.3 & 2.5 & 0.18 & 0.48 & 0.18 & 0.25 \\
\hline
\end{tabular}

The heating/cooling loads for the commercial building during the 49 years from 1961 to 2009 are

Table 1. Summary of the design parameters for selected commercial and residential buildings.

Note: HTC, heat transfer coefficient; T, Temperature; RH, Relative humidity; ACR, Air change rate 

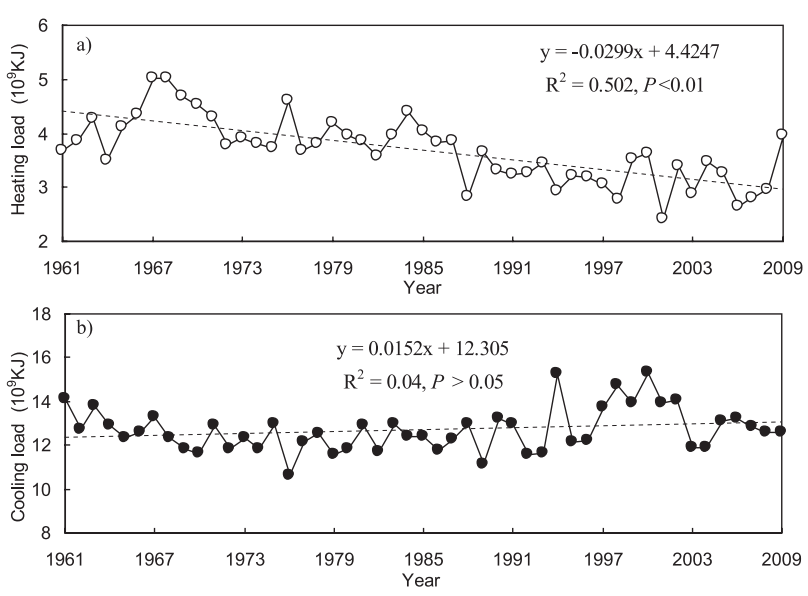

Fig. 2. Interannual variations in energy load for heating a) and cooling b) in commercial buildings, 1961-2009.

shown in Fig. 2. For the heating period, a significant decrease in the energy requirement for heating was observed in commercial buildings $\left(\mathrm{R}^{2}=0.502, P<0.01\right)$ with a decreasing rate of $0.29 \times 10^{9} \mathrm{~kJ} / 10 \mathrm{a}$ (Fig. 2a). There were apparent inter-annual fluctuations in the heating load of the commercial building. From 1961 to 1968, an increase in the heating load was found, followed by an apparent decline until 1998. Thereafter, no obvious changes in the heating load occurred. In contrast to the heating load, the cooling load showed a weak but not significant increase in the cooling period $\left(\mathrm{R}^{2}=0.04, P>0.05\right)$, with an increasing rate of $0.15 \mathrm{~kJ} / 10 \mathrm{a}$ (Fig. 2b). From 1961 to 1993 there was no change trend in the cooling load, followed by an obvious increase from 1994 to 2002 and no further change from 2003 to 2009.

The annual variations in heating load for residential buildings with different energy-saving standards are shown in Fig. 3. The heating load significantly decreased from 1961 to 2009 for all of the different energy-saving standard residential buildings $\left(\mathrm{R}^{2}>0.5\right.$, $P<0.01$ ). The heating load increased from 1961 to 1967 , followed by a decrease until 1998 and no obvious trend, but large fluctuations thereafter. The changing trend

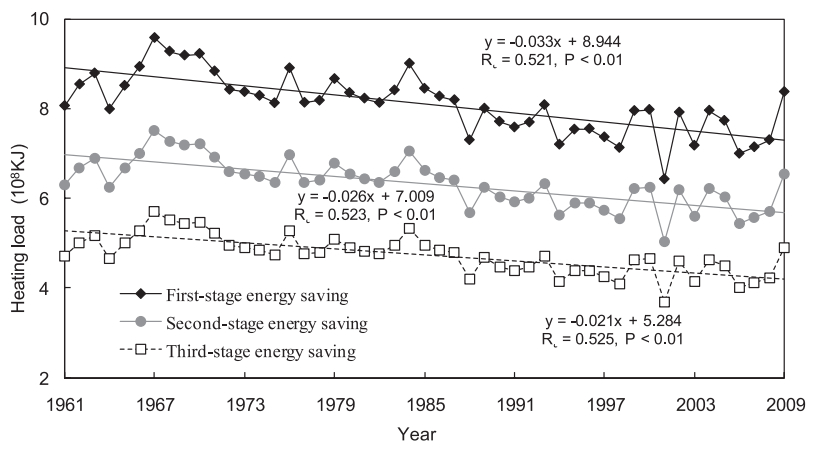

Fig. 3. Interannual variations in energy load for heating in residential buildings with different energy-saving standards, 1961-2009. was similar in the first- to third-stage energy-saving residential buildings; however, the first-stage energysaving residential building $\left(8.1 \times 10^{8} \mathrm{~kJ}\right)$ had a much higher average heating load than the second-stage energy-saving building $\left(6.3 \times 10^{8} \mathrm{~kJ}\right)$. The third-stage energy-saving building had the lowest heating load $\left(4.7 \times 10^{8} \mathrm{~kJ}\right)$. The decreasing rate of heating load from 1961 to 2009 gradually decreased from the first- to the third-stage energy-saving buildings (Fig. 3), indicating that sensitivity to climate change decreased with the enhancement of the energy-saving standards.

\section{Energy Load in Relation to Climatic Parameters}

To explore the potential factors affecting the variations in the heating/cooling loads for each month of the heating or cooling periods, a forwardselection stepwise regression that included variables representing the dominant possible climatic parameters was performed. Table 2 presents the results from the multiple stepwise linear regressions for the commercial building. Climate parameters explained, on average, up to $96 \%$ of the interannual variation in heating load using one-, two-, three-, and four-factor stepwise linear regression models. More importantly, the additional variation explained in the two-, three-, and fourfactor models is minimal compared with the variation explained by the one-factor model (Table 2). Thus, it was primarily focused on the results of the one-factor model. Negative relationships with the mean temperature were found in all months of the heating period, with $\mathrm{R}^{2}$ values as high as 0.93 . This indicates that the heating load is dominantly affected by mean temperature, although other factors such as solar radiation, wet bulb temperature in January, solar radiation in February, minimum temperature in March, minimum temperatue and maximum temperature in November, maximum temperature, wind speed, and minimum temperature in December also entered the regression models. These climatic parameters only explained minimal fractions of the variations of the heating load in the commercial building.

In contrast with the heating load, the first factor entered for the one-factor model showed differences in different months for the cooling load (Table 3). In June and September, the minimum temperature or mean temperature entered as the most important variable in the one-factor model, and the wet bulb temperature also entered the two-factor models. Additionally, climate parameters explained $80 \%, 89 \%$, and $93 \%$ of the interannual variations in the commercial building cooling load using one-, two-, and three-factor models, respectively. In July and August, wet bulb temperature first entered the regression model and explained 98\% and $96 \%$ of the interannual variations in cooling load using one-factor models (Table 3). Although the maximum temperature also entered the two-factor model, it only minimally explained the variation of the 
Table 2. Results from the stepwise multiple linear regression of the heating load for a commercial building against the climatic parameters $(\mathrm{n}=49)$; adjusted $\mathrm{R}^{2}$ are given; ***indicates significance $P<0.001$.

\begin{tabular}{|c|c|c|c|c|}
\hline & One-factor model & Two-factor model & Three-factor model & Four-factor model \\
\hline \multirow{3}{*}{ January } & $-4406780 \times \mathrm{MET}$ & $-4453133 \times \mathrm{MET}$ & $-44044338 \times \mathrm{MET}$ & \\
\hline & & $-192208 \times \mathrm{SR}$ & $-254480 \times \mathrm{SR}$ & \\
\hline & & & $-484021 \times$ WBT & \\
\hline Constant & $2.6 \times 10^{7}$ & $2.7 \times 10^{7}$ & $2.6 \times 10^{7}$ & \\
\hline $\mathrm{R}^{2}$ & $0.997^{* * *}$ & $0.998^{* * * *}$ & $0.998^{* * *}$ & \\
\hline \multirow{2}{*}{ February } & $-3761065 \times \mathrm{MET}$ & $-3762462 \times \mathrm{MET}$ & & \\
\hline & & $-2506.4 \times \mathrm{SR}$ & & \\
\hline Constant & $2.8 \times 10^{7}$ & $2.6 \times 10^{7}$ & & \\
\hline $\mathrm{R}^{2}$ & $0.981^{* * *}$ & $0.983^{* * *}$ & & \\
\hline \multirow{2}{*}{ March } & $-2734684 \times \mathrm{MET}$ & $-1818258 \times \mathrm{MET}$ & & \\
\hline & & $-1051983 \times$ MIT & & \\
\hline Constant & $2.7 \times 10^{7}$ & $2.3 \times 10^{7}$ & & \\
\hline $\mathrm{R}^{2}$ & $0.933^{* * *}$ & $0.939^{* * *}$ & & \\
\hline \multirow{3}{*}{ November } & $-2788735 \times \mathrm{MET}$ & $-2069198 \times \mathrm{MET}$ & $297742.2 \times \mathrm{MET}$ & \\
\hline & & $-760451 \times \mathrm{MIT}$ & $-1979387 \times$ MIT & \\
\hline & & & $-1136151 \times$ MAT & \\
\hline Constant & $2.7 \times 10^{7}$ & $2.4 \times 10^{7}$ & $2.4 \times 10^{7}$ & \\
\hline $\mathrm{R}^{2}$ & $0.927^{* * *}$ & $0.936^{* * *}$ & $0.953^{* * *}$ & \\
\hline \multirow{4}{*}{ December } & $-4030035 \times \mathrm{MET}$ & $-3713604 \times \mathrm{MET}$ & $-3359158 \times \mathrm{MET}$ & $-1980838 \times \mathrm{MET}$ \\
\hline & & $-385088 \times$ MAT & $-559265 \times$ MAT & $-1080462 \times$ MAT \\
\hline & & & $564886.5 \times W S$ & $535718.8 \times W S$ \\
\hline & & & & $-911656 \times$ MIT \\
\hline Constant & $2.8 \times 10^{7}$ & $2.9 \times 10^{7}$ & $2.9 \times 10^{7}$ & $2.8 \times 10^{7}$ \\
\hline $\mathrm{R}^{2}$ & $0.975^{* * *}$ & $0.978^{* * *}$ & $0.980^{* * *}$ & $0.981^{* * *}$ \\
\hline
\end{tabular}

Note: MET, mean temperature; MIT, minimum temperature; MAT, maximum temperature; SR, solar radiation; WBT, wet bulb temperature; WS, wind speed.

cooling load. The combined results above indicate that the cooling loads for commercial buildings are driven by different climate parameters in different months. At the early and late months of the cooling period, the cooling load appears to be most sensitive to temperature, i.e., the mean or minimum temperature, whereas the cooling load is dominantly affected by the wet bulb temperature in the middle of the cooling period. This suggests that under high temperature conditions, not only temperature but also humidity account for the interannual variations in the cooling load.

Table 4 shows the results from the stepwise multiple linear regressions for residential buildings with different energy-saving standards. The mean temperature explained, on average, $99 \%$ of the interannual variations in the heating load using the one-factor models for all residential buildings with different energy-saving standards. The additional variations explained in the two-, three-, and four-factor models are minimal compared with the variation explained by the one-factor model because no apparent increases in $\mathrm{R}^{2}$ were found with the addition of other variables (Table 4). Therefore, the mean temperature may be the most important factor affecting the heating load for residential buildings.

\section{Discussion and Conclusions}

This study investigated the variations of the heating/ cooling energy loads for commercial and residential buildings and the impacts of climate parameters on energy load. The results indicate that heating energy loads for commercial and residential buildings decreased significantly from 1961-2009, whereas energy load in the 
Table 3. Results from the stepwise multiple linear regression of the cooling energy load for a commercial building against the climatic parameters $(\mathrm{n}=49)$; adjusted $\mathrm{R}^{2}$ are given; $* * *$ indicates significance $P<0.001$.

\begin{tabular}{|c|c|c|c|}
\hline & One-factor model & Two-factor model & Three-factor model \\
\hline \multirow{3}{*}{ June } & $7278605 \times$ MIT & $4377347 \times$ MIT & $1684716 \times \mathrm{MIT}$ \\
\hline & & $6233348 \times$ WBT & 7351732*WBT \\
\hline & & & $2804925 \times$ MAT \\
\hline Constant & $-5.8 \times 10^{7}$ & $-1.2 \times 10^{8}$ & $-1.7 \times 10^{8}$ \\
\hline $\mathrm{R}^{2}$ & $0.737^{* * *}$ & $0.859^{* * * *}$ & $0.932^{* * *}$ \\
\hline \multirow{2}{*}{ July } & $18000000 \times \mathrm{WBT}$ & $17000000 \times$ WBT & \\
\hline & & $777382.1 \times$ MAT & \\
\hline Constant & $-2.7 \times 10^{8}$ & $-2.8 \times 10^{8}$ & \\
\hline $\mathrm{R}^{2}$ & $0.978^{* * *}$ & $0.982^{* * *}$ & \\
\hline \multirow{2}{*}{ August } & $16000000 \times \mathrm{WBT}$ & $16000000 \times$ WBT & \\
\hline & & $1103889 \times$ MAT & \\
\hline Constant & $-2.4 \times 10^{8}$ & $-2.6 \times 10^{8}$ & \\
\hline $\mathrm{R}^{2}$ & $0.958^{* * *}$ & $0.961^{* * *}$ & \\
\hline \multirow{3}{*}{ September } & $8173923 \times \mathrm{MET}$ & $5414126 \times$ MET & $6992922 \times$ MET \\
\hline & & $3621961 \times$ WBT & 4215348*WBT \\
\hline & & & $-1957566^{*}$ MIT \\
\hline Constant & $-1.1 \times 10^{8}$ & $-1.24 \times 108$ & $-1.3 \times 10^{8}$ \\
\hline $\mathrm{R}^{2}$ & $0.853^{* * *}$ & $0.915^{* * *}$ & $0.920^{* * *}$ \\
\hline
\end{tabular}

Note: MIT, minimum temperature; WBT, wet bulb temperature; MAT, maximum temperature; MET, mean temperature

cooling period did not show significant variation despite a weak increasing trend. Therefore, the decreased energy load for winter heating due to climate change should be recognized, and energy saving measures (e.g., changes in building envelope and retrofitting of existing heating systems) will improve building heating energy efficiency.

In accordance with the decrease in heating energy load, many published papers have shown a decreasing trend in heating energy consumption estimated by heating degree-days and attributed this phenomenon to the continuous increase in temperature [9, 11]. However, these studies also conclude that energy load for cooling, by calculating cooling degree days, has increased significantly in recent years, which is different from the results in this study. This may be because the cooling energy load in this study is related to not only temperature but also humidity, especially in the midsummer cooling period (Table 3). By contrast, the previous studies only used the cooling degree days based on the variations of temperature, although some previous studies used novel methods [9-11]. For example, Papakostas et al. [11] analyzed the impact of ambient temperature increase on the heating and cooling energy loads in residential buildings by calculating degreedays with a variable base of $4 \mathrm{~h}$. The combined effects of other climate parameters, especially humidity, should be considered to determine the climate effect on cooling energy load.

This study demonstrates that, with the increase in energy-saving standards, heating energy load decreased. The first-stage energy-saving residential buildings consume $22.2 \%$ more energy than the second-stage energy-saving buildings, and the energy load of the third-stage buildings represents only approximately $74.4 \%$ of the second-stage energy-saving residential buildings. Compared with the first stage, the thirdstage energy saving residential buildings can save nearly $58.0 \%$ of the heating energy load. Therefore, decreases in energy load reach the requirements of the standards of residential building energy-saving design. The distinctions among the different energy savingstandards of residential buildings mainly exist in the building envelope and window-to-wall ratio, according to the residential building energy conservation design standard (Table 1). Changes in the building envelope, as one of the most efficient mitigation measures, have been widely used to mitigate the increase in building energy consumption $[2,6]$. From the viewpoint of heat transfer, the building envelope is an efficient shelter for reducing heat gain in the summer and heat loss in the winter [19]. From the first- to the thirdstage energy-saving residential buildings, the heat transfer coefficient (HTC) of the residential building 


\begin{tabular}{|c|c|c|c|c|c|c|c|c|c|c|c|c|c|c|c|c|c|c|c|c|c|c|c|c|c|}
\hline 紫 & 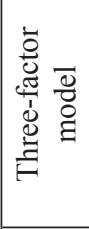 & 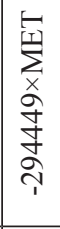 & 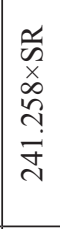 & $\left|\begin{array}{c}0 \\
\tilde{n} \\
x \\
o \\
\infty \\
\vec{\Xi} \\
\vdots \\
1\end{array}\right|$ & 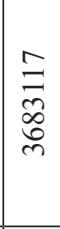 & 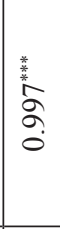 & 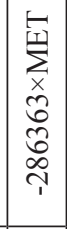 & 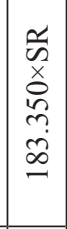 & 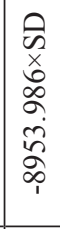 & 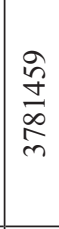 & 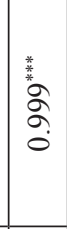 & 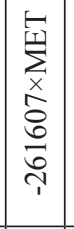 & 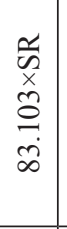 & 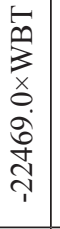 & $\begin{array}{l}R \\
\stackrel{2}{0} \\
\stackrel{i}{c} \\
\tilde{m}\end{array}$ & 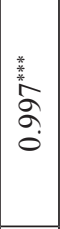 & & & & & 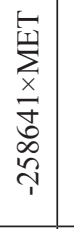 & 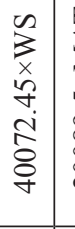 & 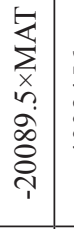 & 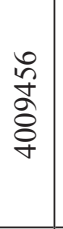 & 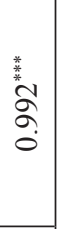 \\
\hline 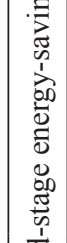 & 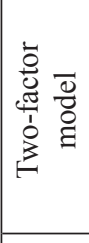 & 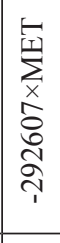 & 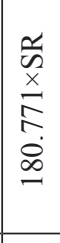 & & 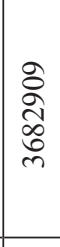 & 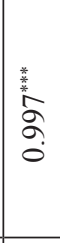 & 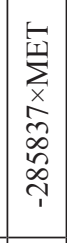 & 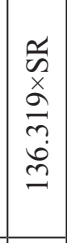 & & 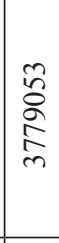 & 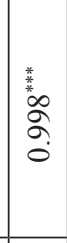 & 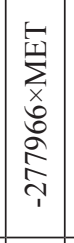 & $\begin{array}{l}\frac{a}{\tilde{n}} \\
x \\
\underline{m} \\
\overrightarrow{0} \\
0\end{array}$ & & $\mid \begin{array}{c}\infty \\
\stackrel{n}{\hat{N}} \\
\tilde{N} \\
m\end{array}$ & 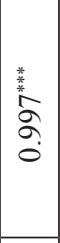 & & & & & 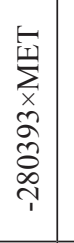 & 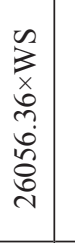 & & $\begin{array}{l}\hat{o} \\
0 \\
\stackrel{n}{n}\end{array}$ & 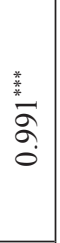 \\
\hline 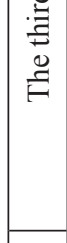 & 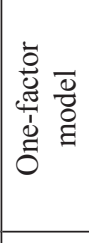 & 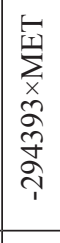 & & & $\begin{array}{l}\infty \\
\tilde{n} \\
\hat{\tilde{N}} \\
\infty \\
\infty \\
n\end{array}$ & 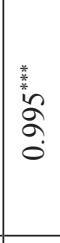 & 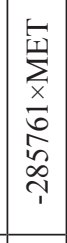 & & & $\begin{array}{l}\overrightarrow{\tilde{n}} \\
\tilde{a} \\
\tilde{n}\end{array}$ & 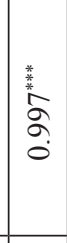 & 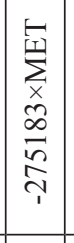 & & & $\mid \begin{array}{l}0 \\
\infty \\
\infty \\
\infty \\
\infty \\
\infty \\
m\end{array}$ & $\mid \begin{array}{l}\mid \\
0 \\
0 \\
0 \\
0 \\
0\end{array}$ & 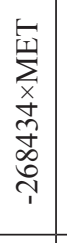 & & $\begin{array}{l}\overrightarrow{\widehat{D}} \\
\hat{\Delta} \\
\infty \\
\infty\end{array}$ & $\begin{array}{l}\frac{*}{2} \\
\tilde{z} \\
\vdots \\
0\end{array}$ & 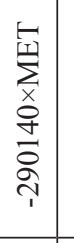 & & & $\begin{array}{l}\text { ô } \\
\text { ఫे } \\
\text { oे }\end{array}$ & $\begin{array}{l}\text { 美 } \\
\stackrel{2}{\circ} \\
\stackrel{0}{0}\end{array}$ \\
\hline 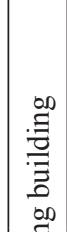 & 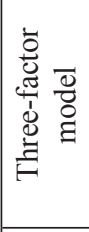 & 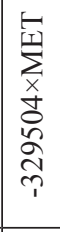 & 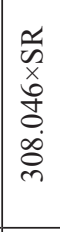 & 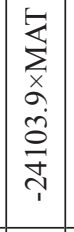 & $\frac{a}{\tilde{6}}$ & 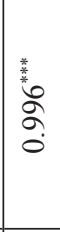 & & & & & & & & & & & & & & & 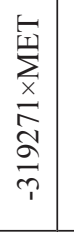 & 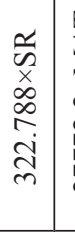 & 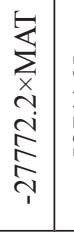 & 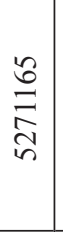 & 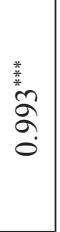 \\
\hline 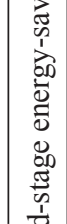 & 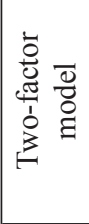 & 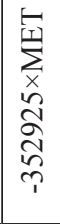 & 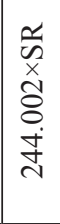 & & 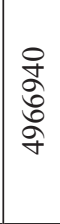 & 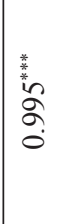 & 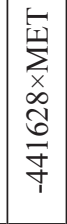 & 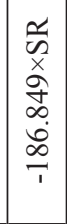 & & 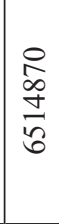 & 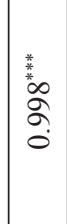 & 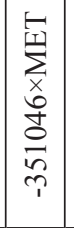 & $\begin{array}{l}\tilde{w} \\
\hat{x} \\
\hat{n} \\
\hat{n} \\
\hat{b} \\
\underline{n}\end{array}$ & & $\begin{array}{l}0 \\
n \\
0 \\
0 \\
0 \\
n\end{array}$ & 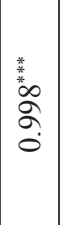 & & & & & 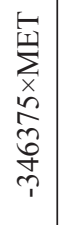 & 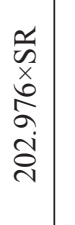 & & 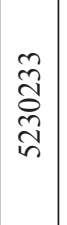 & $\begin{array}{l}\frac{.}{1} \\
\stackrel{5}{\circ} \\
\stackrel{0}{0}\end{array}$ \\
\hline 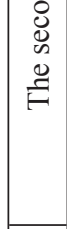 & 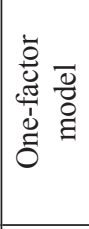 & 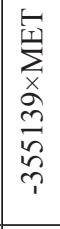 & & & $\begin{array}{l}\hat{\tilde{n}} \\
\hat{n} \\
\hat{n} \\
i \vec{n}\end{array}$ & 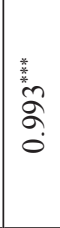 & 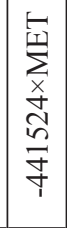 & & & 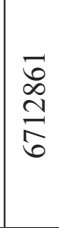 & 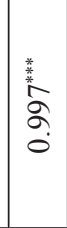 & 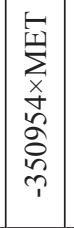 & & & $\begin{array}{l}2 \\
\infty \\
\infty \\
\omega \\
\hat{~} \\
n\end{array}$ & 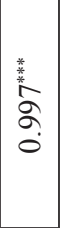 & 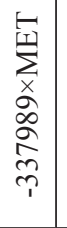 & & 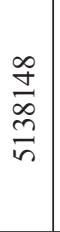 & $\begin{array}{l}\frac{*}{*} \\
\infty \\
2 \\
\vdots \\
0\end{array}$ & 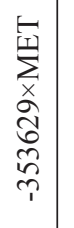 & & & $\begin{array}{l}n \\
0 \\
0 \\
0 \\
n \\
n\end{array}$ & 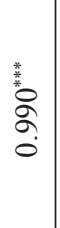 \\
\hline 告 & 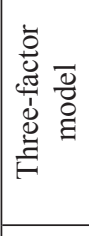 & 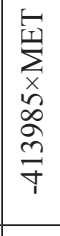 & 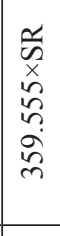 & 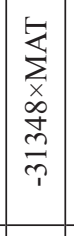 & $\begin{array}{l}n \\
0 \\
0 \\
\hat{0} \\
0 \\
0\end{array}$ & 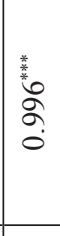 & & & & & & 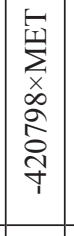 & 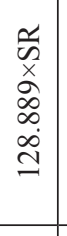 & 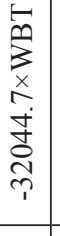 & 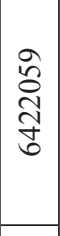 & 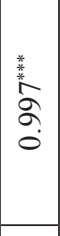 & & & & & 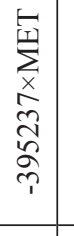 & 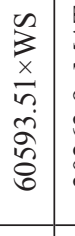 & 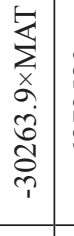 & $\begin{array}{l}0 \\
\infty \\
\tilde{N} \\
\infty \\
0\end{array}$ & 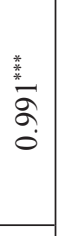 \\
\hline 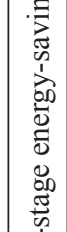 & 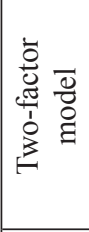 & 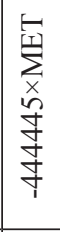 & 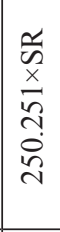 & & $\begin{array}{l}\widehat{\hat{\alpha}} \\
\infty \\
\infty \\
\hat{b}\end{array}$ & 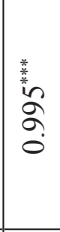 & 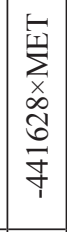 & 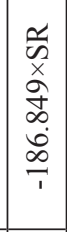 & & $\begin{array}{l}\stackrel{p}{\infty} \\
\stackrel{\infty}{+} \\
\hat{\delta}\end{array}$ & 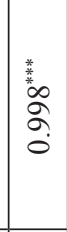 & 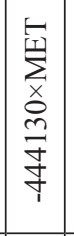 & 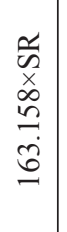 & & 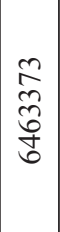 & 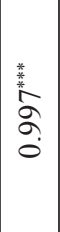 & 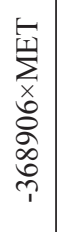 & 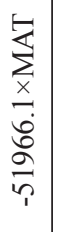 & 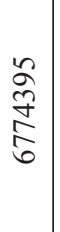 & 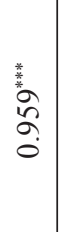 & 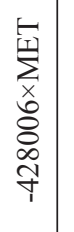 & 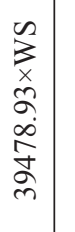 & & 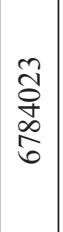 & 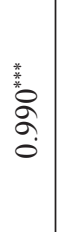 \\
\hline $\begin{array}{l}\text { 邑 } \\
\text { 足 }\end{array}$ & 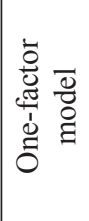 & 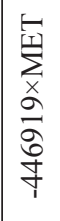 & & & $\begin{array}{l}\vec{\infty} \\
\tilde{2} \\
\infty \\
\hat{b}\end{array}$ & 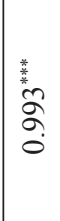 & 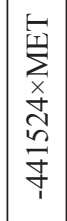 & & & 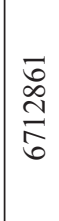 & 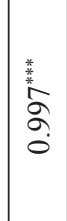 & 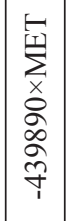 & & & $\mid \begin{array}{c}0 \\
0 \\
0 \\
0 \\
0 \\
0 \\
0\end{array}$ & 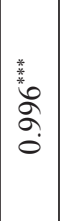 & 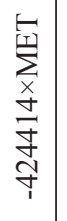 & & $\begin{array}{l}\hat{2} \\
\tilde{n} \\
\tilde{c}\end{array}$ & $\begin{array}{l}\frac{1}{2} \\
\dot{0} \\
2 \\
o \\
0\end{array}$ & 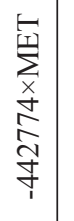 & & & $\begin{array}{l}\infty \\
0 \\
\hat{0} \\
0 \\
0 \\
0\end{array}$ & 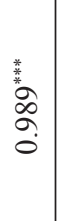 \\
\hline & & & 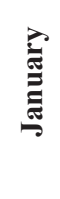 & & 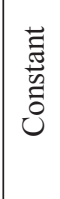 & $\approx$ & & है & & 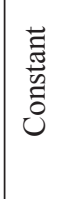 & $\approx$ & & 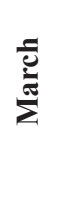 & & 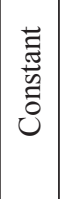 & $\approx$ & $z$ & & 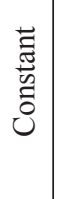 & $\approx$ & & 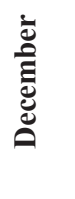 & & 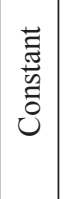 & $\approx$ \\
\hline
\end{tabular}


envelope decreased, which largely contributes to the decrease in energy consumption. In addition, the window-to-wall ratios also partly account for the variations in energy consumption of residential buildings with different energy-saving standards. With the increasing energy saving standards, the interannual changing rates of the heating load of residential buildings decreased from 1961 to 2009. The rate of decrease was $0.337 \times 10^{8} \mathrm{~kJ} / 10 \mathrm{a}$ for the first-stage energy-saving residential buildings and $0.269 \times 10^{8} \mathrm{~kJ} / 10 \mathrm{a}$ and $0.219 \times 10^{8} \mathrm{~kJ} / 10 \mathrm{a}$ for the second- and third-stage energy-saving residential buildings, respectively. This indicates that buildings with high energy-saving standards not only consume less energy but also exhibit a relatively lower sensitivity to climate change, especially climate warming. Developing high energy-saving standard buildings will be beneficial for improving human comfort and reducing $\mathrm{CO}_{2}$ emissions.

In the present study, the heating and cooling loads of commercial building as well as heating loads of residential buildings during the periods of 1961-2009 in Tianjin, a large city in northern China, were simulated and then their responses to climate change were analyzed. In summary, energy loads for heating in commercial and residential buildings showed a large and significant decrease over 49 years, which was dominantly driven by the increase in temperature - especially mean temperature. In contrast, the cooling energy load in commercial buildings did not increase significantly because cooling energy is controlled not only by temperature but also by humidity (especially in the midsummer). This indicates that possible temperature increase in the future may not largely drive increasing of energy load for cooling, and the combined effects of the climate parameters should be considered. The interannual variations of energy load for heating in residential buildings with different energy-saving standards indicate that energy-saving measures decrease not only building energy load but also its sensitivity to climate change.

\section{Acknowledgements}

This work was financially supported by the Climate Change Special Funding Project (CCSF201831, CCSF201614) of the China Meteorological Bureau.

\section{References}

1. LAM J.C., WAN K.K.W., LAM T.N.T., WONG S.L. An analysis of future building energy use in subtropical Hong Kong. Energy, 5, 1482, 2010.

2. WAN K.K.W., LI D.H.W., LAM J.C. Assessment of climate change impact on building energy use and mitigation measures in subtropical climates. Energy, 36, 1404, 2011a.

3. CAI W.G., WU Y., ZHONG Y., REN H. China building energy consumption: situation. challenges and corresponding measures. Energy Policy, 37, 2054, 2009.

4. YAO R.M., LI B.Z., STEEMERS K. Energy policy and standard for built environment in China. Renewable Energy, 30, 1973, 2005.

5. BUTLER D. Architecture: architects of a low-energy future. Nature, 452, 520, 2008.

6. WANG X.M., CHEN D., REN Z.G. Assessment of climate change impact on residential building heating and cooling energy requirement in Australia. Building and Environment, 45, 1663, 2010.

7. WAN K.K.W., LI D.H.W., LIU D.L., LAM J.C. Future trends of building heating and cooling loads and energy consumption in different climates. Building and Environment, 46, 223, 2011b.

8. LI M.C., CAO J.F., GUO J., NIU J.D., XIONG M.M. Response of energy consumption for building heating to climate change and variability in Tianjin City, China. Meteorological Applications, 23, 123, 2016.

9. JIANG F.Q., LI X.M., WEI B.G., HU R.J., LI Z. Observed trends of heating and cooling degree-days in Xinjiang Province, China. Theoretical and Applied Climatology, 97, 349, 2012.

10. YOU Q.L., ERAEDRICH K., SIELMANN F., MIN J.Z., KANG S.C., JI Z.M., ZHU X.H., REN G.Y. Present and projected degree days in China from observation, reanalysis and simulations, Climate Dynamics, 43(5-6), 1449, 2014.

11. PAPAKOSTAS K., MAVROMATIS T., KYRIAKIS $\mathrm{N}$. Impact of the ambient temperature rise on the energy consumption for heating and cooling in residential buildings of Greece. Renewable Energy, 5, 1376, 2010.

12. MCGILLIGAN C., NATARAJAN S., NIKOLOPOULOU M. Adaptive comfort degree-days: a metric to compare adaptive comfort standards and estimate changes in energy consumption for future UK climates. Energy and Buildings, 3, 2767, 2011.

13. LI M.C., GUO J., TIAN Z., SHI J., XIONG M.M., XIANG C. Future climate change and building energy demand in Tianjin, China, Building Services Engineering Research and Technology, 35(4), 362, 2014.

14. MENG F.C., LI M.C., CAO J.F., LI J., XIONG M.M., FENG X.M., REN G.Y. The effects of climate change on heating energy consumption of office buildings in different climate zones in China. Theoretical and Applied Climatology, DOI 10.1007/s00704-017-2206-6, 2017.7,

15. CHEN Y.H., LI M.C., XIONG M.M., CAO J.F., LI J. Future climate change on energy consumption of office buildings in different climate zones of China. Polish Journal of Environmental Studies, 2017.

16. LI M.C., SHI J., GUO J., CAO J.F., NIU J.D., XIONG M.M. Climate impacts on extreme energy consumption of different types of buildings. PLOS ONE, DOI:10.1371/ journal. pone.0124413. 2015.

17. CAO J.F., LI M.C., WANG M., XIONG M.M., MENG F.C. Effects of climate change on outdoor meteorological parameters for building energy-saving design in the different climate zones of China. Energy and buildings, 146, 65, 2017.

18. STULL R. Wet-bulb temperature from relative humidity and air temperature. Journal of Applied Meteorological and Climatology, 50(11), 2267, 2011.

19. CHAN A.L.S. Developing future hourly weather files for studying the impact of climate change on building energy performance in Hong Kong. Energy and Buildings, 43, 2860, 2011 
